\title{
Physicochemical Analyses of Burkina Fasan Honey
}

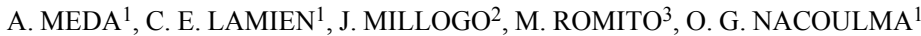 \\ ${ }^{1}$ Laboratoire de Biochimie et Chimie Appliquées, U.F.R./ S.V.T, Université de Ouagadougou, Burkina Faso \\ ${ }^{2}$ Laboratoire de Biologie et d'Ecologie Végétales, U.F.R./ S.V.T, Université de Ouagadougou, Burkina Faso \\ ${ }^{3}$ Biotechnology Division, Onderstepoort Veterinary Institute, South Africa
}

Received August 16, 2004

Accepted March 3, 2005

\begin{abstract}
Meda A., C.E. Lamien, J. Millogo, M. Romito, O.G. Nacoulma: Physicochemical Analyses of Burkina Fasan Honey. Acta Vet. Brno 2005, 74: 147-152.

This study intended to determine and compare the microscopic and physicochemical characteristics of Burkina Fasan honey $(n=27)$ with those described in the Codex Standard, and to also find correlations between individual constituents. Physicochemical properties were determined using the harmonised methods of the international honey commission.

Microscopic pollen analyses identified the samples as being derived from one Acacia, one Lannea, three Vitellaria, two Combretaceae, two mixed Poaceae honeydew and eighteen multifloral honey. Despite the tropical ambient temperature, all the samples were nevertheless well within the limits of the Codex Standard for levels of hydroxymethylfurfural, reducing sugars, proline and diastase activity. Only $7.4 \%$ (ash), $14.8 \%$ (free acidity and $\mathrm{pH}$ ) and $22.2 \%$ (moisture) of samples exceeded the Codex-permitted limits. A highly significant correlation was found between $\mathrm{pH}$ and ash content $(\mathrm{r}=0.77 ; P<0.001)$.

The training of non-professional beekeepers in beekeeping practice is suggested to improve the quality of Burkina Fasan honey.
\end{abstract}

Quality control, chemical composition, pollen analysis, correlation

The reason for testing honey for quality control purposes is to verify the authenticity of the product and to reveal the possible presence of artificial components or adulterants, as well as to address processing and market needs (Krell 1996). This requires not only determining the moisture and mineral content (ash), but also the levels of hydroxymethylfurfural (HMF), acidity, diastase activity, apparent sugars and water insoluble solids (Bogdanov et al. 1999).

Value limits, as defined internationally by the European Honey Directive and the Codex Alimentarius, for honey of declared origin from tropical regions like Burkina Faso, are amounts of not more than 50 milliequivalents of free acidity, $20 \%$ moisture, $0.6 \mathrm{~g} \cdot 100 \mathrm{~g} \mathrm{~g}^{-1}$ for general honey ash and $80 \mathrm{mg} \cdot \mathrm{kg}^{-1}$ for HMF. In addition, values of not less than 8 for diastase activity, $60 \mathrm{~g} \cdot 100 \mathrm{~g}^{-1}$ for reducing sugars and $180 \mathrm{mg} \cdot \mathrm{kg}^{-1}$ for proline levels are prescribed. Some of these limits differ for honeydew honey, viz. not less than $45 \mathrm{~g} \cdot 100 \mathrm{~g}^{-1}$ for reducing sugars and not more than $1 \mathrm{~g} \cdot 100 \mathrm{~g}^{-1}$ for ash content (Codex Alimentarius 2001; Bogdanov and Martin 2002; Bogdan ov et al. 1999; The Council of the European Union 2002).

Despite the many scientific investigations into the physicochemical and enzymatic constituents of honey, further investigations are needed in countries like Burkina Faso where such data is lacking. Since 1983, studies have been carried out in various regions of this country to characterise the bee species present, with the intention of promoting beekeeping. An inventory of melliferous plant species and traditional beekeeping practices has also been described (Guinko et al. 1987; Guinko et al. 1989a; No mbré et al. 2002). The aim of this study was to evaluate and compare the quality of some samples based on physicochemical 
properties of Burkina Fasan honey with the Codex Standard, and to determine whether any compositional relationships exist between local honey.

Honey sampling

\section{Materials and Methods}

27 honey samples were collected. 17 samples $(1,2,3,6,10,11,13,14,15,16,18,19,24,25,26,27)$ were mostly obtained from non-professional beekeepers, $3(4,8,9)$ from the Fada Beekeeping Cooperative (east of Burkina Faso), $2(12,17)$ from the Apiculture Research Centre (Centre de Production, de Formation et de Recherche en Apiculture; CPFRA) and $5(7,20,21,22,23)$ were local commercial honey. Samples were collected from separate hives within one month after extraction during July 2003. Samples from the cooperative and the research centre were harvested from December 2002 to July 2003. The commercial honeys were sampled in July 2003 without certainty of the harvest period. All the samples were stored between $0{ }^{\circ} \mathrm{C}$ and $4{ }^{\circ} \mathrm{C}$.

Qualitative microscopic analysis of honey samples and the determination of frequency classes of pollen grains were done as described (Moar 1985). Acetolysed slides were made from $10 \mathrm{~g}$ samples of honey (Louveaux et al. 1978) and these were compared with published photographs of different pollens (Association des Palynologues de Langue Française 1974; Bonnefille and Riollet 1980) and with reference slides from the Laboratory of Biology and Ecology, University of Ouagadougou.

The physicochemical properties

Were determined according to the Harmonised Methods of the International Honey Commission (Bog danov 1999). The individual constituents were determined using standard procedures as described (B ogdanov 1999):

- Moisture was determined using a honey hand refractometer (HHR-2N, ATAGO, Tokyo, Japan).

- $\mathrm{pH}$ and free acidity were determined by titration to $\mathrm{pH} 8.3$.

- Ash content was determined after the sample was burnt in an electric furnace (Thermolyne type 48000, U.S.A).

- Hydroxymethylfurfural (HMF) content was based on UV absorbance at $284 \mathrm{~nm}$ (CECIL CE 2041 spectrophotometer 2000 series, CECIL Instruments, Cambridge, England) using the method of White (Bog da n ov 1999).

- Apparent reducing sugars were determined as described (Ross 1959).

- Diastase activity was determined using the method of Schade et al. (Bogdanov 1999).

- Proline content was determined using the method of Ough et al. as adapted by Bogdan ov (1999).

Statistical analyses:

All the determinations were carried out in triplicate and the means and standard deviations were calculated using MS Excel software. Correlation coefficients (R) for two variables were calculated using Sigmastat 2.0 Jandel Scientific software (Person Product Moment Correlation function).

\section{Results and Discussion}

Several quality variables for 27 local honey samples were analysed and recorded viz. $\mathrm{pH}$, HMF, moisture, diastase, reducing sugars, free acidity, ash, proline levels and microscopic pollen analysis (Table 1).

Pollen analyses allowed for the identification of seven unifloral, 2 mixed Poaceae honeydew and 18 multifloral honey samples. The unifloral honeys were classed as being 2 Combretaceae honeys (64.9\% and $82.8 \%$ ), 3 Vitellaria honeys $(81.4 \%, 90.1 \%$ and $84.8 \%)$ and 1 Acacia $(59.2 \%)$ and 1 Lannea honey (94.5\%). The pollen analyses showed more multifloral (67\%) than unifloral (26\%) and honeydew honeys (7\%).

The free acidity varied from $20.3 \pm 0.4$ to $60.8 \pm 0.4 \mathrm{meq} \cdot \mathrm{kg}^{-1}$. When considering the new limit for free acidity permitted by the Codex (2001) and the European Community Directive (The Council of the European Union 2002), only the 2 eastern Poaceae honeydew honey samples from the eastern part and 1 Vitellaria (south-western part) and 1 multifloral (central part) honey were outside the legislation limits. A high free acidity value was obtained for some honeydew honey from Morocco (Diez et al. 2004) which indicated a tendency to ferment.

Honey $\mathrm{pH}$ values varied from $3.5 \pm 0.1$ to $4.7 \pm 0.1$. Published reports indicate that $\mathrm{pH}$ should be between 3.2 and 4.5 (Bogdanov 1995). According to these values, 1 Vitellaria honey from the central part, 1 Poaceae honeydew honey and 2 multifloral honeys from the south-western part were outside this range. The mean values, however, only indicated that the central Vitellaria honey were outside this range $(4.6 \pm 0.1)$. Some honeys, such as chestnut and fir honey have been shown to have high $\mathrm{pH}$ values viz. 5-6 and 4.6-5.9, 
respectively (Bogdanov 1995). The $\mathrm{pH}$ values of the 2 honeydew honeys were similar to those of honeydew honey from the Czech Republic (4.53) (Čelechovská and Vorlová 2001) and some Moroccan honeydew honey (Diez et al. 2004).

The moisture content varied from $15.0 \pm 0.1$ to $25.1 \pm 0.0 \%$. The Acacia honey, 1 Combretaceae honey and 4 multifloral honeys exceeded the permitted limit of $20 \%$ (Codex Alimentarius 2001) and can be mainly explained by the premature extraction of these honeys. This can lead to a greater risk for fermentation.

The most commonly monitored parameters for determining honey freshness include HMF levels and diastase and invertase activity (Oddo et al. 1999; Bogdanov and Martin 2002). The latter two are included as international quality standards for honey (Codex Alimentarius Commission 1969; European Economic Community 1974). According to our findings $\mathrm{HMF}$ levels ranged from $2.0 \pm 0.2$ to $41.9 \pm 0.1 \mathrm{mg} \cdot \mathrm{kg}^{-1}$ and the diastase activity varied from $6.5 \pm 0.5$ to $62.3 \pm 2.3$. All the honey samples were well inside the current Codex Standard for HMF and confirmed the young age of the samples. The central multifloral honey showed the best mean HMF value $\left(10.6 \pm 10,5 \mathrm{mg} \cdot \mathrm{kg}^{-1}\right)$ with a high mean diastase number $(22.0 \pm 5.9)$ in comparison with those from the eastern and the south-western parts (Table 1). The multifloral honey sample with 6.5 Schade units could be qualified as a honey with low natural enzyme content (Codex Alimentarius 2001).

The proline content varied from $437.82 \pm 23.04$ to $2169.37 \pm 18.39 \mathrm{mg} \cdot \mathrm{kg}^{-1}$. The mean proline values of the multifloral honey were very similar (Table 1). Some authors have reported that high values for proline are typical for honeydew honeys (Di ez et al. 2004). In our study, the proline content of 2 honeydew honey were $437.8 \pm 23.0$ and $687.6 \pm 19.8$ $\mathrm{mg} \cdot \mathrm{kg}^{-1}$ but were not the highest values found. However, these values were higher than those of some groups of Moroccan honeydew honeys, which reportedly varied from 69 to 556 $\mathrm{mg} \cdot \mathrm{kg}^{-1}$ (Diez et al. 2004). Authors such as Louveaux (1985) believe that the majority of the proline comes from bee salivary secretions. Proline content has been shown to vary considerably between different honeys (Bogdanov et al. 1999). In our study, the highest proline contents were obtained with the 3 Vitellaria honeys which also had the highest antioxidant activities (unpublished data). It has been shown that some amino acids have antioxidant properties (Wu et al. 2003).

The values for reducing sugars $\left(67.30 \pm 1.9\right.$ to $\left.96.20 \pm 6.4 \mathrm{~g} \cdot 100 \mathrm{~g}^{-1}\right)$ were within the limits listed in the Codex Alimentarius (2001). These values, however, seemed to be higher than those for commercial honey from Australia, China, Egypt, Germany, Morocco, Pakistan, Qatar, USA, Italy and Yemen (Al-Jedah et al. 2003).

The ash content varied from $0.130 \pm 0.056$ to $0.947 \pm 0.048 \mathrm{~g} \cdot 100 \mathrm{~g}^{-1}$. The two highest ash values were observed in the 2 mixed Poaceae honeydew honeys. According to the Codex Standard for honeydew or mixed honeydew ash content (Bogdanov 1995), these values confirmed the findings of the pollen analyses of the two samples. Some authors have reported that honeydew and/or mixed honeys have the highest ash content (Kirkwood et al. 1960; Bogdanov et al. 1999). High ash content has been obtained in Moroccan and Czech honeydew honeys (Diez et al. 2004). One central Vitellaria honey and one eastern multifloral honey had ash contents outside this range.

Kirkwood et al. (1960), using the discriminant function $\left(X=x_{1}+x_{2}+x_{3}\right)$ in which $x_{1}$ is the $\mathrm{pH}, \mathrm{x}_{2}$ is the percentage of ash and $\mathrm{x}_{3}$ is the percentage of reducing sugars, found values of $X=86.7$ for authentic floral honey and $X=57.6$ for honeydew honey. Accordingly, the two mixed honeydew honeys $(X=82.9$ and $X=75.5)$ could be classed here as floral or mixed honey.

Considering the physicochemical characteristics obtained for different Burkina Fasan honey samples, $22.2 \%$ (moisture), $14.8 \%$ (free acidity and $\mathrm{pH}$ ), and $7.4 \%$ (ash) of samples exceeded the Codex permitted limits, with a highly significant correlation between $\mathrm{pH}$ and 


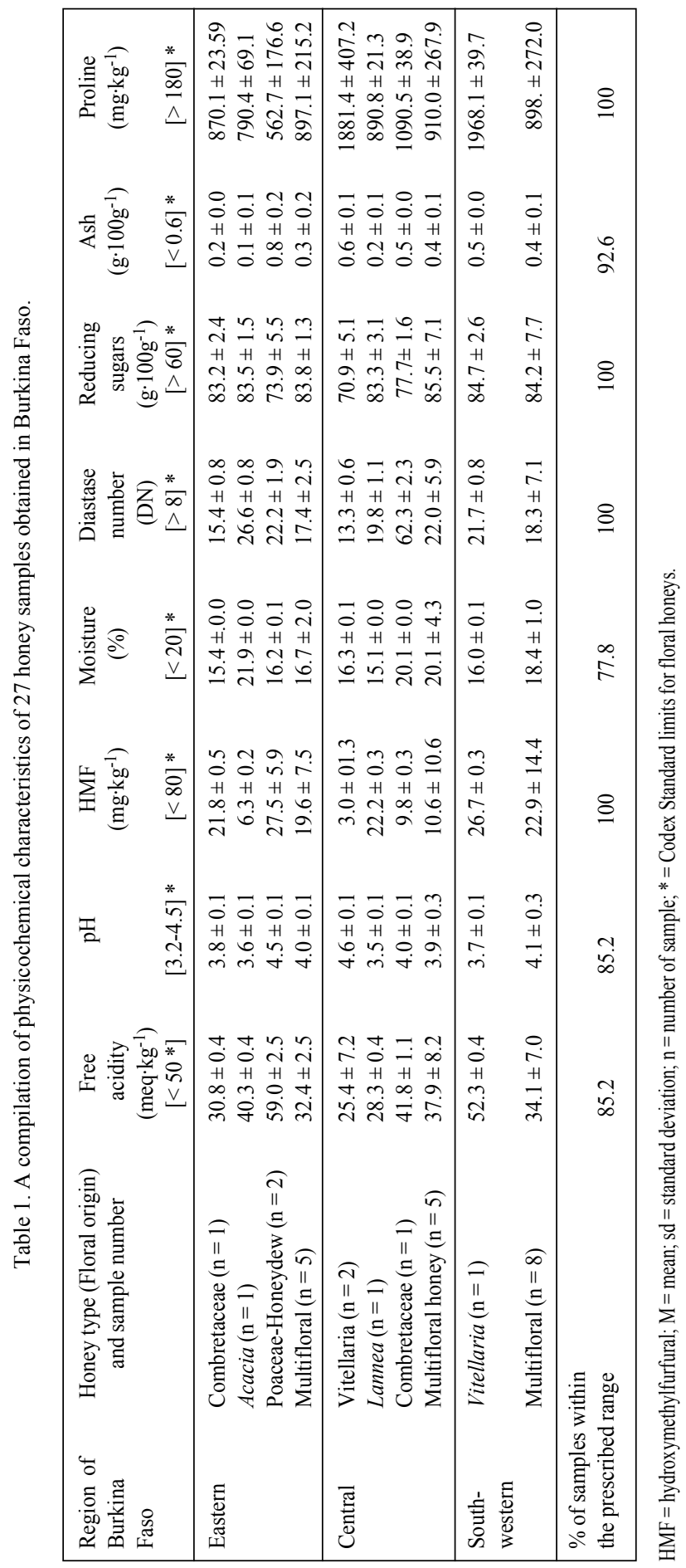


ash content ( $\mathrm{R}=0.77 ; P<0.001)$ (Fig. 1). This finding has also been described by Čelechovská and Vorlová (2001). A negative correlation was obtained between HMF and moisture $(\mathrm{R}=-0.51 ; P<0.05)$ (not shown). There was no significant relationship between the other variables (not shown).

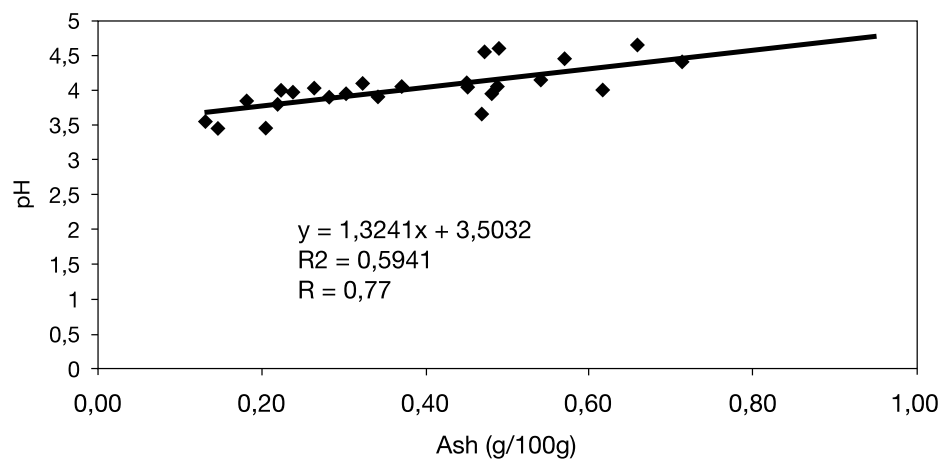

Fig. 1. Regression line for ash contents and $\mathrm{pH}$ values of various honey samples analysed.

In conclusion, our study obtained physicochemical data for several Burkina Fasan honey derived from flowers of Combretaceae, Acacia, Lannea and Vitellaria species. The pollen analyses of the 2 mixed Poaceae honeydew honey were confirmed by the ash content and partly by the discriminant function of Kirkwood et al. (1960).

This study has shown that honey derived from both non-professional and professional Burkina Fasan beekeepers as well as commercial honey, are of a good quality in respect to physicochemical variables like HMF, diastase, proline and reducing sugar levels. Sample freshness was determined because of the tropical ambient temperature of the country, using HMF levels and diastase activity. A highly significant correlation was shown between $\mathrm{pH}$ and ash content and almost every sample was within the current standard for moisture and free acidity levels. The high levels of reducing sugars warrants further investigations to determine acceptable limits for other Burkina Fasan honey. Honey quality (based on moisture, HMF, free acidity and $\mathrm{pH}$ levels) could be improved by the training of nonprofessional Burkina Fasan beekeepers in honey harvesting and storage.

\section{Fyzikálně-chemická analýza medů z Burkina Faso}

Tato studie byla provedena za účelem zjištění a srovnání mikroskopických a fyzikálněchemických vlastností medů z Burkina Faso (27) s medy popsanými v Codex Alimentarius, a také zjistit vzájemné korelace mezi jednotlivými složkami. Fyzikálně-chemické vlastnosti byly stanoveny s využitím harmonizovaných metod International Honey Commission.

Mikroskopickou analýzou pylu bylo určeno že vzorky pocházejí z medovice rostlin: 1 Acacia, 1 Lannea, 3 Vitellaria, 2 Combretaceae, směsi 2 Poaceae a 18ti medů z více rostlin. Navzdory tropickým teplotám prostředí byly všechny vzorky v limitech Codex Standard pro: hydroxymethylfurfural, redukující cukry, prolin, aktivitu amylázy. Kodexem stanovené limity byly překročeny jen hodnotami popela $(7.4 \%)$, kyselosti a pH (14.8\%) a vlhkosti $(22.2 \%)$. Mezi $\mathrm{pH}$ a obsahem popela byl zjištěn vysoce signifikantní vztah $(\mathrm{r}=0.77 ; P<0.001)$. Autoři navrhují školení neprofesionálních včelařu v chovu včel za účelem zlepšení kvality medu z Burkina Faso. 


\section{Acknowledgment}

This research was supported financially by the Swedish International Foundation for Science (IFS) by means of a fellowship (E-3331-E) granted to the main author.

\section{References}

AL-JEDAH, HJ, MARTIN, P, ROBINSON RK 2003: Compositional differences between brands of honey on sale in Qatar. Applied Biotechnology, Food Science and Policy 1: 69-73

ASSOCIATION DES PALYNOLOGUES DE LANGUE FRANÇAISE 1974. Pollen et spores d'Afrique tropicale. Trav. et Docum. Géogr. Tropicale, 16, CEGET, Talence, 283 p.

BOGDANOV, S, BIERI, K, FIGAR, M, FIGUEIREDO, V, IFF,D, KANZIG, A, STOCKLI, H, ZURCHER, K 1995: Miel: définition et directives pour l'analyse et l'appréciation. Centre Suisse de recherche Apicole; Station de recherches laitières, Liebefeld, Berne

BOGDANOV, S, MARTIN, P 2002: Honey authenticity. In: Mitteilungen aus den Gebiete der Lebensmitteluntersuchung und Hygiene 93: 232-254

BOGDANOV, S 1999. Harmonised methods of the international honey commission. Swiss Bee Research Center, FAM, Liebefeld, Bern, Switzerland

BOGDANOV, S, LÜLLMANN, C, MARTIN, P, VON DER OHE, W, RUSSMANN, H, VORWOHL, G, ODDO, LP, SABATINI, AG, MARCAZZAN, GL, PIRO, R, FLAMINI, C, MORLOT, M, LHERETIER, J, BOMECK, R, MARIOLEAS, P, TSIGOURI, A, KERKVLIET, J, ORTIZ, A, IVANOV, T, D'ARCY, B, MOSSEL, B, VIT, P 1999: Honey quality, methods of analysis and international regulatory standards: review of the work of the International Honey Commission. Mitt Lebensm Hyg 90: 108-125

BONNEFILLE, R, RIOLLET, G 1980: Pollens des savanes d'Afrique orientale. Editions du CNRS, France

ČELECHOVSKÁ, O, VORLOVÁ, L 2001: Groups of honey-Physicochemical properties and heavy metals. Acta Vet Brno 70: $91-95$

CODEX ALIMENTARIUS 2001: Revised standard for honey. Codex Standard 12-1981. Rev 1 (1987), Rev 2 (2001), Rome: FAO

CODEX ALIMENTARIUS COMMISSION 1969: Recommended European Regional Standards for Honey. (CAC/RS 12-1969) FAO and WHO, Rome

DIEZ, MJ, ANDRES C, TERRAB, A 2004: Physicochemical parameters and pollen analysis of Moroccan honeydew honey. Int J Food Sci Tech 39: 167-176

EUROPEAN ECONOMIC COMITY 1974: EEC Council directive of 22 July 1974 on the harmonization of the laws of the member states relating to honey. Off J Eur Comm L221: 10-14

GUINKO, S, GUENDA, W, MILLOGO-RASOLODIMBY, J, TAMINI, Z, ZOUNGRANA, I 1987: Etude des plantes mellifères dans l'ouest du Burkina Faso (provinces du Houet, Comoé, Kénédougou). Projet TCP /BKF/4510 (T) "Développement de l'Apiculture",

GUINKO, S, GUENDA, W, MILLOGO-RASOLODIMBY, J, TAMINI, Z, ZOUNGRANA, I 1989: Rapport semestriel sur: Etude des plantes mellifères dans trois provinces du Burkina Faso (Houet, Comoé, Kénédougou) saison pluvieuse. Projet BKF /87/016 "Intensification de 1'Apiculture en Paysanat"

KIRKWOOD, KC, MITCHELL, TJ, SMITH, D 1960: An examination of the occurrence of honeydew in honey. Analyst 85: 412-416

KRELL, R 1996: Value-added products from beekeeping. In: FAO Agricultural Services Bulletin No. 144, Rome, ISBN: 92-5-103819-8

LOUVEAUX, J, MAURIZIO, A, VORWOHL, G 1978: Methods of melissopalynology. Bee World 59: 139-157

LOUVEAUX, J 1985: Le miel. Cahier Nutritionel et Dietetique 20: 57-70

MOAR, NT 1985: Pollen analysis of New Zealand honey. New Zealand J Agric Res 28: 39-70

NOMBRÉ, I, SAWADOGO, M, BOUSSIM, IJ, GUINKO, S 2002: Beekeeping in Burkina Faso. Bees for Development Journal 65: 9

ODDO, LP, PIAZZA, MG, PULCINI, P 1999: Invertase activity in honey. Apidology 30: 57-65

ROSS, AF 1959: Dinitrophenol method for reducing sugars. The Avi. Publishing Company, First edition, Westport

THE COUNCIL OF THE EUROPEAN UNION 2002: Council Directive 2001/110/ec of 20 December 2001 relating to honey. Official Journal of the European Communities L10: 47-52

WU, HC, SHIAU, CY, CHEN, HM, CHIOU, TK 2003: Antioxidant activities of carnosine, anserine, some free amino acids and their combination. J Food and Drug Analys 11:148-153 